\title{
Idioms and Idiotisms: Theodore Thass-Thienemann's The Interpretation of Language and Spectral Inheritance
}

\section{György Fogarasi}

\begin{abstract}
The late work of the Hungarian émigré linguist and comparatist, Theodore Thass-Thienemann, presents a challenging combination of psychoanalytic discourse and the historical study of languages. His two-volume book entitled The Interpretation of Language (1973) sets out to complement the Freudian analysis of dream images and bodily symptoms via an investigation into the symbolism of ordinary verbal expressions as they appear in the languages of Indo-European cultures. His attention to the unconsciously inherited dimensions of particular idioms opens a path to the linguistic archeology of the human mind and a rethinking of the very notion of "idiom" in terms of "idiotism." After providing a brief overview of the life and late works of Thass-Thienemann, this study offers a comprehensive analysis of his book. Drawing on related essays written during the 1950s and 1960s as well as the 1984 manuscript of a projected but unfinished third volume, this analysis does not only attempt to spell out the stakes and insights of ThassThienemann's endeavor, but also to critically identify and examine some of the blind spots his discourse seems unable to overcome, such as his eurocentric and anthropocentric stance. In the final analysis, Thass-Thienemann appears as the provocative thinker of a spectral inheritance, from which even his own discourse is not exempt.
\end{abstract}

Keywords: psychoanalysis, language, symbolism, idiom, spectrality, animality

Biography: György Fogarasi is an Associate Professor of Comparative Literature at the University of Szeged, Hungary. He has published essays in the fields of rhetoric, aesthetics, (post)romantic literature, and critical theory. Beyond his numerous essays on romanticism and theory, he is also the Hungarian translator of Paul de Man's Allegories of Reading, Edmund Burke's Philosophical Enquiry, and Marc Redfield's The Rhetoric of Terror. He has edited volumes addressing the stakes of romantic theory, deconstructive readings of the epitaphic tradition, economic theology, and theories of theatricality and performativity. His book, Necromanticism and Critical Theory (with analyses of texts by Gray, Wordsworth, Marx, and Benjamin), was published in 2015. His current book project, Targets of Attention, contains essays on the idiom of attention and its relation to technology, terrorism, and theatricality.fogarasi@hung.u-szeged.hu

A leading Hungarian linguist and scholar of comparative literature, Tivadar Thienemann (1890-1985) left behind a robust career marked by numerous publications, three academic positions, two periodicals, a book series, and a publishing house, when in 1947 he decided to move from Hungary. After spending a year in Belgium, Thienemann later arrived in the United States where, other than maintaining a teaching position, he worked as a psychiatrist and

(cc) BY

ULIS D-ferle
New articles in this journal are licensed under a Creative Commons Attribution 4.0 International License.

This journal is published by the University Library System of the University of Pittsburgh as part of its D-Scribe Digital Publishing Program and is cosponsored by the University of Pittsburgh Press 
Fogarasi, György. “Idioms and Idiotisms: Theodore Thass-Thienemann's The Interpretation of Language and Spectral Inheritance." Hungarian Cultural Studies. e-Journal of the American Hungarian Educators Association, Volume 12 (2019) DOI: 10.5195/ahea.2019.349

independent scholar until his death at the age of ninety-five. This essay will survey the "American" phase of Thienemann's career, with special attention on the articles and books he wrote during his emigration as "Theodore Thass-Thienemann." It will particularly focus on his two-volume book that appeared in 1973, The Interpretation of Language. Situated at the intersection of psychoanalysis and the historical study of languages, this work is at times bluntly metaphysical (from the perspective of its universalistic and humanistic claims), yet also boldly provocative due to its fascination with the etymological or associative entanglements of specific word clusters that traverse linguistic, historical and cultural borders. It is precisely this ambivalence which renders this work not only enigmatic, but also challenging for analysis. In what follows, I argue that Thienemann's late work formulates what could be called a spectral logic of linguistic inheritance. Before venturing on to a closer analysis, however, it seems practical to give a brief summary of his life and works, as well as an overview of the late writings and their reception so far.

After pursuing studies not only in Budapest (where he was born), but also at universities in Leipzig and Berlin, Thienemann grew into a fully-fledged Germanist who additionally possessed a mastery of both Latin and French (as well as, to some extent, Greek, Sanskrit, and Finnish), and held professorships first at the University of Bratislava, then at the University of Pécs, where he reached the summit of his university career serving as dean between 1925 and 1926. In 1922, he founded the Minerva Society, which published the periodical Minerva, a journal devoted to the promotion of Geistesgeschichte in the humanities by combining philosophical speculation with an interest in literary analysis and an erudition in history in order to counterbalance the positivist tendency toward scientific specialization and fragmentary academic expertise. His comprehensive monograph, Irodalomtörténeti alapfogalmak ['Basic Concepts of Literary History’], was initially published in Minerva in serial form between 1927 and 1930, then reissued in book format in 1931. Thienemann became a member of the Hungarian Academy of Sciences at a relatively early age in 1923. In 1930 he was awarded the Corvin Wreath, the highest official acknowledgment for intellectuals in contemporary Hungary. Thus, by the 1940s, he was fully established in academic circles and would have certainly remained so had not the course of history and political change forced him to start a new life outside of the country. At the time of his emigration he was nearly sixty years old. Rather than retiring, he embarked upon new directions in research and started an "exploratory pilot study" that delved into the unconsciously symbolic dimensions of language (1973:2:229), a project that combined his expertise in the history of languages and literatures with a growing interest in psychoanalysis and related modes of interpretation.

Beside a few articles or notes published between 1955 and 1963 ("A Comment on an Interpretation by Prof. Cadbury," "Left-Handed Writing," "Oedipus and the Sphinx," "The Art of Counseling," "The Talking Teapot," or "Psychotherapy and Psycholinguistics"), Thienemann's late work consists of two bulky books published in 1967 and 1968, The Subconscious Language and Symbolic Behavior. Almost eighty years old at this point, he was still full of ambition to make his findings widely known on North American soil. Although reactions to his work were rather disparate (as is clear from his own need to respond to some of the reviews about the first of these books, cf. Thass-Thienemann 1969), on the whole he seemed optimistic about their reception. He warmly welcomed the project of an Italian translation and ultimately decided to republish the two volumes jointly, in reverse order, as The Interpretation of Language I-II (1973), with Symbolic Behavior appearing as Volume One (Understanding the 
Fogarasi, György. “Idioms and Idiotisms: Theodore Thass-Thienemann's The Interpretation of Language and Spectral Inheritance." Hungarian Cultural Studies. e-Journal of the American Hungarian Educators Association, Volume 12 (2019) DOI: 10.5195/ahea.2019.349

Symbolic Meaning of Language), and The Subconscious Language reissued as Volume Two (Understanding the Unconscious Meaning of Language). In subsequent years Thienemann initiated a follow-up project on The Influence of Literacy upon Thinking, which by 1984 resulted in another book that was intended to be Volume Three of his late opus magnum. Consisting of four parts ${ }^{1}$ (out of which only the latter three seem to have been completed), this unfinished and untitled book project remained in manuscript not only for the rest of Thienemann's life, but also until today. It is now part of the collection of his manuscripts deposited at the National Széchényi Library in Budapest (fond 152, box 3). Apart from these publications, a recent collection of autobiographical essays and notes (Az utókor címére, 2010 ['To the Address of Posterity']), and a number of private letters, some of which have been sporadically published in various Hungarian periodicals, testify to the personal and intellectual itinerary of the émigré Theodore Thass-Thienemann.

Beyond the difficulties posed by language and accessibility, its strangeness is probably one of the reasons why The Interpretation of Language has gained relatively sparse attention among the otherwise devoted Hungarian readers of Thienemann. In his country of origin, a revived interest in his works has centered on his mid-career book, Basic Concepts, as a contribution to literary studies and has foregrounded freshly attained perspectives in media theory, as well as related sociological and historical engagements with the changing technologies and practices of literary production, dissemination and reading. In a lucid essay, which is most probably the only elaborate analysis to date written in English on Thienemann's thought, András Kiséry clearly places Basic Concepts at the top of Thienemann's achievements, showing little interest in the closer examination of the late work, which is nevertheless acknowledged as "an erudite combination of etymological and semantic investigation with psychoanalytic thought" (Kiséry 2011: 43). Interestingly enough, even more recent essays expressly devoted to the Interpretation fail to engage this work analytically. One critic prefers to sketch out what Thienemann should have written, rather than examine what he actually wrote (Pléh 2016), while the Hungarian translator of the first volume of the Interpretation understandably chooses to give a more general overview of the project itself and does not even pretend to perform an in-depth analysis (Simoncsics 2016). Apart from sporadic mentions (mostly in studies written in English), ${ }^{2}$ some of which celebrated Thienemann as a modern Vico, included him in the prestigious company of Freud, Jung, and Lacan, or coupled him with Norman O. Brown as a major figure in psychoanalytic literary criticism, no sustained analysis has yet been devoted to the two-volume late work, except for the persistent but still fragmentary interest shown throughout Péter Dávidházi's book Menj, vándor ['Go, Wanderer']. For Dávidházi, the Interpretation is the fitting late counterpart, and in some ways even the continuation, of the insightfulness of the Basic Concepts (see especially Dávidházi 2009: 71), an accomplishment

1 The four parts are titled "The Royal Road: The Logical Analysis and Psychoanalysis of Language," "Beyond the Royal Road: Toward an Ordinary Language Psychology," "The Illiterate Mind," and "The Literate Mind." (For the sake of accuracy, references to this manuscript will also include the number for the part being referred to.)

${ }^{2}$ For a few examples, see Rogers 1978: 9, 136, 138, Kugler 2002 (1982): 32-36, 83-85, Avilés 1999: 41-48, Pesaresi 2000: 482 (cf. Dávidházi 2009: 71), Fónagy 2001: 661, Balogh 2013: 128, 133, and Dávidházi 2016: 37. 
Fogarasi, György. "Idioms and Idiotisms: Theodore Thass-Thienemann's The Interpretation of Language and Spectral Inheritance." Hungarian Cultural Studies. e-Journal of the American Hungarian Educators Association, Volume 12 (2019) DOI: 10.5195/ahea.2019.349

that still awaits due recognition (Dávidházi 2010: 13, cf. Koncz 2010: 151).

To be sure, it is not at all certain that one could, or even should, go beyond fragmentary remarks when assessing the findings and merits of the Interpretation of Language. Thienemann, who as a linguist also participated in the editing of dictionaries during his years in Hungary, clearly does not want to produce a monolithic narrative or a single line of argument, but instead prefers to formulate a multitude of interrelated explications that provide clues concerning the unsuspected implications of our cultural heritage. Although these explications of meaning are intended to offer more than what the alphabetically ordered and numerically segmented entries of dictionaries usually do, they are still much more rudimentary and divergent than a coherent argumentation would normally be. Beyond numerous in cross-references, repetitions, or overlaps, they also contain lacunae and even inconsistencies. And since one does not read dictionaries (or dictionary-like manuals as this one is) as an essay is read, the fragmentary character of the critical commentary is perhaps less a deficiency than an accurate replication (or even an unavoidable effect) of the text under scrutiny. Yet since the first volume promises some fundamental principles (1973: 1:vi), it also makes us expect a more linear argument, even though in this volume (especially in its "Addenda," but also in Part 3) one already finds several chapters consisting solely of word cluster explications. In what follows, I will critically examine the major points of this argument with necessary references to the second volume, as well as to the earlier articles from the 1950s and 1960s and the unfinished manuscript of the third volume.

The Interpretation of Language clearly and admittedly strives to continue Freud's Interpretation of Dreams with the important difference of transposing the scope of inquiry from phantasmatic images within dreams (or daydreams) to words and their multiple levels of meaning within ordinary language. Thienemann claims that psychoanalytic discourse in fact anticipates this move not only with the Freudian interest in jokes or slips of the tongue, or with the introduction of linguistic terminology (terms like "symbol," "expression," "meaning," or "interpretation") into the analysis of dreams and bodily symptoms $(1973: 1: 7,116)$, which made psychoanalysis a kind of psycholinguistics avant la lettre (1963: 38), but also by taking major elements of its theoretical vocabulary from the lexicon of everyday life, as for instance, the notion of "mental energy" is picked up from the imagery of modern household electricity (1984: Part 2, 43). It is from this angle that Thienemann criticizes the abstractness of standard English translations of key psychoanalytic concepts (the all-too-Latinate terms of "Ego," "Id," "interpretation," "cathexis," or "instinct") (1984: Part 2, 18-18a). In view of Freud's interest and openness toward everyday life and vocabulary, Thienemann finds it all the more interesting how ordinary language still remains a "blind spot" for him (1973:1:7), as he never in fact endeavored to explore the implicit symbolism of everyday expressions, even though he acknowledged the potential gains of such a project. As Thienemann puts it, Freud "stated that we would understand the language of the dream better if we knew and had an adequate analysis of language. He contributed himself to the fabulous expansion of psychoanalytical insight into the various fields of art and literature — only language itself remained exempt from intensive analytical interpretation" (1973: 1:7). Thienemann purports to remedy this flaw in psychoanalytical practice. His aim is to replace the interpretation of dreams, which Freud considered the "royal road" to a knowledge of the unconscious, by the public highway offered by languages (1973: 2:1, 1984: Part 4, 138). 
Fogarasi, György. “Idioms and Idiotisms: Theodore Thass-Thienemann's The Interpretation of Language and Spectral Inheritance." Hungarian Cultural Studies. e-Journal of the American Hungarian Educators Association, Volume 12 (2019) DOI: 10.5195/ahea.2019.349

With this Freudian introduction of linguistic terminology into psychoanalysis, the etiological investigation into the hidden causes of symptoms is turned into an interpretive investigation concerning hidden layers of meaning. With Thienemann's shift of focus from dream content to linguistic material, a further displacement takes place that supplants etiology in favor of etymology, in which perceptible symptoms and imperceptible thoughts or sentiments appear in the form of the contemporary face value and the forgotten underlying sense of verbal expressions. Transposed into the realm of language, the Freudian archeology of the unconscious becomes a linguistic archeology or paleontology (1973: 1:64, 2:225), whereby one might successfully uncover the "forgotten language of unconscious fantasies" (1955b: 241). Thienemann attempts to recall, for instance, the "forgotten language of the eye" by showing how the eye appears as a "window" of the body as house (1955a: 21, 1973: 1:252-55). With the displacement of interpretation from dreams (and bodily symptoms) to language, the relation between latent and manifest dimensions reappears as the etymological link between the visible stem and the invisible roots of a given word (1973: 1:78-79, 1984: Part 3, 85).

For Thienemann, however, psycholinguistic analysis is not restricted to etymological exploration. While he makes good use of the imagery of archeology both in the sense of the excavation of fragments and the restoration of a lost whole (1973: 1:viii, 123), he is clearly interested in more than the mere reconstruction of a genealogical ancestry. His reliance on a "principle of adaptation" (1973: 1:152-153) includes historical connections that extend beyond the organic relations between words to include linkages based solely upon association through coincidental phonemic similarity (homophony) and semantic transfer between historically unrelated expressions. He quotes Freud's interpretation of a patient's longing "toward Italy" (gen Italien) as a symbolic expression of "genitals" (Genitalien) (1973: 1:167), or the rhyme association of "womb" and "tomb" in Shelley's poetry (1973: 1:170, see Shelley's poem "The Cloud," as well as Oscar Wilde's memorial piece, "The Grave of Shelley"), but also brings his own examples for homophonic words that have a deeper symbolic connection. He extensively demonstrates, for instance, how the verb match meaning "to fit together" and the noun match meaning "the object for lighting" may have their connection in the sexual communion of a couple producing friction and heat (1973: 1:58-63).

In many cases symbolically intertwined words (such as the verbs answer and swear, 1973: 1:52) or interrelated meanings of a single sound pattern (as in the case of the verb ask meaning both "question" and "request," 1973: 1: 51) are undoubtedly also related etymologically. But what really matters to Thienemann is not whether they stem from the same root, but whether they are associatively joined in some repressed unconscious fantasy. Analyzing the symbolic linkage between "plowing" and "playing" in an essay on "Left-Handed Writing," he concludes that "Their coherence may have evolved in a secondary way through convergent development. However, their common origin is not the point in question, but their belonging to a group of interrelated words forming a common sphere of association is from our viewpoint of special relevancy." Thienemann continues on to define "structure" as precisely "such a group of words forming a common network of coherent crossreferences based upon repressed unconscious fantasies" (1955b: 244). The problem with etymological dictionaries, according to Thienemann, is that they cannot account for such nonlinear or retroactive modes of "convergent development." While writers of dictionary entries strive to enumerate all the disparate and isolated meanings of a given word in a single line of explication by composing a genealogical narrative of transitions leading from one meaning to the next through a logic of smooth genetic 
Fogarasi, György. “Idioms and Idiotisms: Theodore Thass-Thienemann's The Interpretation of Language and Spectral Inheritance." Hungarian Cultural Studies. e-Journal of the American Hungarian Educators Association, Volume 12 (2019) DOI: 10.5195/ahea.2019.349

development, for Thienemann, "language does not play this logical domino game" (1973: 1:83). According to him, etymology is legitimate only inasmuch as it is no longer a study of genetic descendance, but rather "a study of motivation" (1973: 1:85), an effort to track down the contingency of projective associations. Such an endeavor remains doubtful concerning its own results and thus willing to question each of its own reconstructions (1973: 1:163).

Of course, as soon as one concludes that vocal language is unintended, spontaneous "somatic expression," the Cratylic idea of motivation brings with itself another potential fallacy, that of the motivated "natural" sign (1973: 1:40, cf. 127). This possibility lurks in the background of Thienemann's analyses. Yet his notion of the spontaneous origination of projected meaning also proves to be a highly productive hypothesis which is responsible for the myriad of imaginative conjectures flooding the first two volumes of the Interpretation. (The manuscript of Volume Three has quite different stakes and thus contains far fewer word explications.) While these commentaries may at times be exceptionally provocative and engaging, they also may appear formidably overwhelming or repetitive, which is perhaps why some of Thienemann's early reviewers had the impression that he was merely producing a "blinding dust storm" by his compulsive "etymological free association" (1969: 172). Given this sharp deviation from a traditionally restricted etymology, it is hardly surprising that there is a tone of uneasiness and embarrassment in the otherwise rather appreciative commentary by Dávidházi, who understandably attempts to maintain a sober distance from Thienemann's aberrantly prolific associations (Dávidházi 2009: 43, 48, 66).

Thienemann is in fact well aware of the dangers of homophonic interpretation. He points out several times how easily historical linguistics can become the playground of dilettantes (1973: 1:164, 169) and, one may add, the battleground of ideological wars concerning the kinship and origin of nations. As I have indicated above, he also maintains a deeper significance for homophony, one connected to the historical evolution of languages, a development which might split even one and the same language into languages according to the idioms of particular speakers. Every language is divided into numberless "personal idioms" based on its users' different experiences and the different memories and ideas they assign to the same words and expressions. While the extent of these differences may of course range from slight variations to radically divergent notions, their very existence is indisputable, as is the interfering communicational "noise" they produce (1973: 2:4). Languages are noisy because they are fundamentally homophonic. Interlocutors never really speak the same language. Even if they perform an exchange in their mother tongue, their dialogue in fact takes the form of an encounter between "two different languages" that overlap coincidentally (1973: 1:13).

The idea of speakers of one and the same language speaking two different languages (reminiscent of Locke's similar claim in the Essay on Human Understanding, 1997: 365), takes Thienemann to the idiom of the term idiom itself. It is at this juncture that Thienemann spells out the specific ways in which the notion of idiom is linked to that of idiotism or idiocy, the implication being that idiosyncratic language use is traditionally held deviant or abnormal, and thus persons with highly peculiar personal idioms who are unable to understand others or make themselves understood have been considered idiots (1973: 1:13). Idiotism may mean both linguistic peculiarity and mental deficiency. Thienemann's ultimate claim is, however, that to a certain extent every single person speaks a peculiar private language, has a personal speech idiom and is - from this perspective - an idiot. Such idiocy is present in all language usage since the singularity of a person's background and education also makes his or her language singular, 
Fogarasi, György. “Idioms and Idiotisms: Theodore Thass-Thienemann's The Interpretation of Language and Spectral Inheritance." Hungarian Cultural Studies. e-Journal of the American Hungarian Educators Association, Volume 12 (2019) DOI: 10.5195/ahea.2019.349

whereby each and every person has a radically individual idiom always bordering on incomprehensibility or the possibility of a potentially fatal misunderstanding. What is more, as far as dream contents and bodily symptoms compose a similar network of idiomatic expressions, people also have their own particular "dream idioms" and "organ idioms" (1973:2:6). Coming back to verbal language, the radically idiomatic character of personal word use is apparent not only in the speech of deviant figures such as schizophrenics or poets, but most commonly in the speech of children, whose private idiom is paradigmatic with regard to language in general.

Whether knowingly or not, Thienemann here still follows the footsteps of Locke, who makes a similar claim concerning the privately idiomatic and thereby homophonic nature of words (see the example of the term gold and its changing connotations in infantile language, Locke 1997: 364-365). Yet Thienemann also follows an English romantic tradition of poetic thought, namely that of Wordsworth, whose lyrical ballad on "The Idiot Boy" is probably the best example of forming a linkage between the figure of the child and the figure of the idiot in terms of idiomatic thought and expression, ${ }^{3}$ and whose line "The child is father of the man" (from another poem, "My Heart Leaps Up") Thienemann quotes in one of his late autobiographical essays as a general piece of wisdom that anticipates Freudian thought, albeit he quotes it with the slightly distortive inaccuracy of an hyperbaton: "The child is the father of man" (Thienemann 2010: 78). The temporal and potentially autobiographical relationship between man and boy, or adult and infant, also implies the possibility that even the same person may not come to terms with himself if the passing of time also means the fading away of past experiences and associations, whereby even the same individual's two personalities (past and present) will speak two different languages connected only by contingent homophony. At other points in the Interpretation, Thienemann lays unequivocal stress on this insight: "even the same person cannot utter exactly the same sentence twice because he is not the same twice" (1973: 1:99), or: "In the reality of historical time, no verbal utterance can be said twice in exactly the same way, in exactly the same situation, just as one cannot step twice in the same river, as Heraclitus said" (1973: 2:226). Language splits into languages and might generate homophonies not only between individuals of the same tongue, but within the privacy of any particular individual, producing momentary idiomatic splinters of language with an irreducible singularity of idiotism. Thus, homophony (or, if one does not want to reduce language to speech: homonymy) is a profound mechanism deeply embedded in language and cannot be taken lightly as a merely marginal and easily avoidable defect. Puns, as Thienemann seems ready to acknowledge, are at the core of thought and expression (1973: 1:167, 177).

Even though Thienemann's explications are not confined to traditional etymological investigations, his interpretive efforts always aim to bring divergent meanings into "one consistent overall unity" (1955b: 260) - if not in the form of a "common origin," then at least in the form of what he calls a "structure" or "system" (a "common sphere" or "common network" of interrelated elements), which still guarantees the homogeneity of an ultimate archaic meaning

\footnotetext{
${ }^{3}$ For a fine commentary on the poem, with a selection of relevant literary and philosophical references, see Avital Ronell's Stupidity (2002: 246-77). As Ronell convincingly shows, eighteenth-century fables of the "wild child" (or of the idiot) purported to present a conjectural "missing link" between nature and man (2002: 269).
} 
Fogarasi, György. “Idioms and Idiotisms: Theodore Thass-Thienemann's The Interpretation of Language and Spectral Inheritance." Hungarian Cultural Studies. e-Journal of the American Hungarian Educators Association, Volume 12 (2019) DOI: 10.5195/ahea.2019.349

lying underneath the surface of ordinary speech (1955b: 244). These explications take the form of a "translation" from the figural to the proper meaning of everyday expressions. Once "properly translated," everyday words like "writing," "left," and "hand" unveil their unconscious contents, bringing us, in this case, to the "proper sense" of "writing with the left hand" (1955b: 241, 253). Pushed to an extreme, translation borders on the comic, as Thienemann summarizes the Oedipus myth ("the limping swollen-footed son met by mere chance his unknown lefthanded, pederast father", 1984: Part 3, 107), or as he rewrites the Cartesian thesis of Cogito ergo sum in a way that boils down to "I suck, therefore I am" (cf. 1973: 1:15). Although he seems reluctant to suggest that his translations of "figurative" speech back into the suppressed and forgotten literal sense would provide an ultimate "true" meaning, his conviction that language is always figurative still urges him to uncover the "hidden underground communication" that lies "repudiated, repressed and forgotten" beneath the surface meaning of speech (1955b: 240-241). Everyday speech is considered deeply figurative for it is nothing but a multitude of dead metaphors which convey latent meanings, inherited from earlier generations, regardless of the intentions of the speaker. And since this unconscious layer of language is "a system of manifold cross-references," every speaker is by necessity "entangled" in a complicated network of such references (1955b: 240), unaware of the latent workings of the language he uses, even or especially when he speaks in his own native language.

At the point of interpretive victory, however, a lurking threat emerges in Thienemann's discourse. If indeed "all good etymologists are fortune hunters and interpreters of dreams," as Thienemann, quoting Karl Vossler, repeatedly claims (1955b: 250, 1973: 1:86), then he himself appears to be a fairly successful hunter of hidden meanings. As we also learn, these meanings can never be accessed easily because "a monstrous paleozoological reptile appears to be the keeper of the underground treasures" (1957a: 31). Challenged by such monsters, Thienemann seems unstoppable in his reach for the underlying treasures of meaning, i.e. in his pursuit of "the same idea" (1957a: 32). But one begins to wonder about the fate of this all-too-victorious hunter as soon as we also learn that even the killing of the mythical monster does not end the calamities of the hero: "All dragon-killer heroes become finally the victims of their victory over unconscious fantasies" (1957a: 31). As we are told, the curse victimizing the victorious hero is that he is prone to become "infatuated" with his own victory. In view of Thienemann's neverfailing hunt for the "one" or the "same" of proper meaning ("one consistent overall unity", "same idea"), we may ask where and how this curse takes place and takes the interpreter as its victim.

In his "Introduction" to the first volume of the Interpretation of Language, Thienemann underscores his commitment to a fresh and unbiased start. He promises the close and unmediated analysis of "verbal material" or "verbal facts," in an effort to "forget the preconceptions" of scientific orthodoxy (tenets mistakenly deduced from anatomy, physiology, and chemistry). His determination to stick to the "evidence" or "testimony" of languages was already asserted in the 1955 essay on "Left-Handed Writing" (1955b: 240, 255). This time, however, he merely seems to replace those scientific dogmas with others, for it is precisely at the moment of getting rid of all "preconceptions" that he immediately formulates his own "basic assumptions" concerning linguistic inquiry: "The basic assumptions, which are maintained in the following presentation, refer to language as a specifically human attribute, to be understood in terms of organic life and development" (1973: 1:2, my emphasis). From the passage that follows, it becomes clear that the modifier "specifically" is to be taken in the most literal sense possible, implying a reference to the human species as opposed to mere "animals": "The thesis maintained is that language is 
Fogarasi, György. "Idioms and Idiotisms: Theodore Thass-Thienemann's The Interpretation of Language and Spectral Inheritance." Hungarian Cultural Studies. e-Journal of the American Hungarian Educators Association, Volume 12 (2019) DOI: 10.5195/ahea.2019.349

human, and human alone. Animals do not speak. No man, however low in culture, was ever found to be without language. No animal, however high in the evolutionary scale, was ever found to possess a language. If an animal could ask an intelligent question, it would have crossed the language barrier and would not be an animal anymore" (1973: 1:2). Thienemann's most basic assumption for his linguistic inquiry is a hypothesis concerning the "language barrier" between humans and animals, a thought he cherishes even in his later years (2010: 19). This assumption is a preconception, for it is taken for granted in advance, and thereby literally pre-conceived. It precludes right from the start any possibility for either humans or animals to cross this barrier, to transgress or alter conceptual boundaries since both are by definition (that is, regardless of any empirical evidence or testimony) conceived inside or outside of language, exclusively inhabiting, or eternally excluded from, its realm. According to this rather traditional (early modern and characteristically Western) metaphysical conception, the animal is denied "organic life and development," it remains an essentially "mechanical" creature, capable only of stagnant, repetitive, motor-response, or reactive behavior, and thus lacking the creativity needed for symbolic action and ultimately for language. In Thienemann's view, language is symbolic behavior at its highest and symbolic behavior presupposes creativity (1973:1:29, 3). While the animal utterly lacks creative powers because it lacks organic spontaneity, man is essentially in possession of "symbolic creativity" (1973: 1:4), is a "symbolic animal" (1973: 1:8, 99, cf. 1984: Part 2, 6), and is in exclusive possession of the "gift" of speech (1973: 1:36, 1984: Part 2, 40).

Somewhat later in the argument of the first volume, however, it turns out that language is not tantamount to symbolism per se. A seemingly casual addition is introduced which nevertheless creates a considerable complication. In the early chapter within Part 1 on "Sign and Symbol," Thienemann argues that language is not necessarily symbolic, but may also operate on a lower level, through mere signs. The distinction drawn just a few pages beforehand between man and animal in terms of language and no language is reformulated here as a distinction between language as symbolism and language as signification: "The difference of function in the meaning of a traffic sign for a dog and the meaning of a religious symbol for the believer is generally understood. It is evident that the sign can function on the subhuman level while the symbol can be understood and created only by the human mind. Animal behavior is conditioned signal behavior; human behavior is essentially symbolic behavior. This makes the cardinal difference between sign and symbol, between animal and man" (1973: 1:20). In this passage, an intralinguistic distinction between symbol and sign supplants the former distinction between a linguistic and a prelinguistic mode of existence. In the context of the "Introduction," the sign is deemed subordinate to the symbol, for it is nothing more than just a "translation," conceived as a mechanical, programmable, and therefore computationally reproducible procedure (1973: 1:4, cf. 110).

Combined with the previous argument about the human-animal divide in terms of language and no language, the passage on sign and symbol suggests that animals do in fact have a language, albeit one which is not quite perfect or complete, not symbolic, and which therefore cannot truly be called a language, for it is merely something that foreshadows real language. It is a kind of half-language, an articulating hinge that mediates between the sheer nonexistence, and the full blossoming, of linguistic capacities. If "Absolute illiteracy perhaps never existed" (1984: Part 4, 111), a purely pre-linguistic state might just as well be a fiction, and language might then be seen as having been with us from the beginning (this "us" being no longer "us humans," and not even "us animals" for sure, but something more difficult to name and outline). Yet, the very 
Fogarasi, György. “Idioms and Idiotisms: Theodore Thass-Thienemann's The Interpretation of Language and Spectral Inheritance." Hungarian Cultural Studies. e-Journal of the American Hungarian Educators Association, Volume 12 (2019) DOI: 10.5195/ahea.2019.349

notion of a half-language would threaten to collapse or blur the initial binary divide between the animal and the human and all the binaries accompanying it (conceptual pairs like repetitive/creative, mechanical/organic, genetic/linguistic, biological/cultural, stagnant/cumulative etc.). To prevent that from happening, Thienemann conducts a permanent war against any such amalgamation. He is resolutely against the contamination of signs and symbols (1973: 1:24), rejects the reduction of symbols to sign-elements (1973:1:25) and is subsequently harshly negative regarding any attempt to trace human language back to a "socalled animal language" (1973: 1:101), even ridiculing the notion of "the animal in man" as nothing more than a "popular science fiction" from the heyday of Freudism (1984: Part 2, 34$35)$.

This anthropocentric "speciesism" (if I may use this term for the tendentious or ideological gesture of uplifting the human at the expense of the animal, and even more importantly, for the gesture of pretending to know in advance what they essentially are) is just one of the two major types of essentialism pervading Thienemann's discourse. The other one is his admittedly eurocentric universalism and obvious preference for the Hebrew-Greek-Roman cultural tradition (1973:2:v) as well as Indo-European culture and Indo-European language (the existence of which, one should note, he does not take for granted but still finds "evident" as something that has been satisfyingly proven, 1973: 1:65). In Volume One, Thienemann only brings a few examples from non-Indo-European languages like Arabic, Egyptian, Hittite, and Japanese. Understandably, somewhat more examples are taken from his mother tongue, Hungarian, a language of Finno-Ugric origin, which can hardly be deemed as untouched by Western heritage. No such examples appear in Volume Two (or in the differently oriented third volume, for that matter). In response to his reviewers, who have reproached him for showcasing Western culture as "universally human," he admits in the "Preface" to Volume One his decision to "stay within the familiar boundaries of our old Western heritage" because of his personal lack of competence in the realm of "aboriginal meanings" outside the West (1973: 1:viii). As regards the former type of essentialism (his devout humanism or "speciesism"), it seems to have gone utterly unnoticed or at least not reflected on either by his critics or himself. As a final move, let us therefore take a closer and possibly critical look at this aspect of Thienemann's endeavor.

As we have seen, the animal first appears as a life form without language, then emerges as a life form capable of language but still incapable of symbolism. Since symbolism is asserted as the quintessence of language, the animal still appears to lack linguistic capability in an essential way. The only mode of transmission it possesses is the half-language of signs. The intermediary image of animal language, and of the "animal" itself, resembles the uncannily transitional figure of the child (itself halfway between man and animal), of whom Thienemann writes that it always exemplifies the "return of the past" (1973: 1:103). Thus, the question of the animal, just as that of the child, can be reformulated as the historical question of a return. How exactly that return takes place in the realm of language is perhaps the greatest insight of Thienemann's investigations since, as he extensively demonstrates, when words change their meanings the old meanings still survive in the newer ones latently, making the past implicitly present and contemporaneous: "Nothing is 'contemporary' without 'past.' The past is 'contemporary,' it is present" (1973: 1:80). The old meanings are "forgotten, stamped out, repressed" (1973: 2:8), but they do not vanish without a trace. And that trace secures them a latent presence and an "aftereffect" (1973: 2:9). Even the most banal sentence can be understood on quite different levels and can say more than the speaker actually intended to say (1973: 1:13). 
Fogarasi, György. “Idioms and Idiotisms: Theodore Thass-Thienemann's The Interpretation of Language and Spectral Inheritance." Hungarian Cultural Studies. e-Journal of the American Hungarian Educators Association, Volume 12 (2019) DOI: 10.5195/ahea.2019.349

This double entendre makes speech fundamentally ambivalent and the speaker "bilingual" (1973: 1:14-15). As mentioned above, Descartes's Cogito ergo sum does not just say "I think thus I am," but due to the implications of the French equivalents of the Latin cogito (penser and savoir), it unintentionally also says, in Thienemann's provocative translation, "I depend or taste, therefore I am," with reference to the primary feeding-sucking experience of early childhood. As a consequence of its permanent ambiguity, language becomes inextricably "parabolic" (1973: 1:49). Beside parables, Thienemann mentions a whole array of literary genres based on disguised ambivalence: fables, proverbs, allegories, riddles, puzzles, maxims, jokes, and even anecdotes (cf. 1984: Part 3, 89). These forms represent an underground dimension of meaning which, without the awareness of the speaker, stays the same and transmits a common "ancient heritage" that underlies the constantly changing surface of individual self-expression. It conveys something "objective" and "transpersonal" (1973: 1:55) and opens the "bottomless pit of the collective unconscious," as in the manuscript of the third volume Thienemann alludes to Jung with a certain amount of sarcasm (1984: Part 2,39) and later notes that "The collective unconscious is just another aspect of the collective heritage called mother tongue" (1984: Part 3, 75).

As secretively operating powers, the old meanings still have an influence which is potentially lethal. While, one the one hand, the man of modernity nourishes a Stoic ideal (cf. 1973: 1:69, 120) and "hopes to overcome the memories which he feels are subhuman and below the dignity of moral self-respect," on the other hand these memories "can persist in a system as a secret source of strength, or as a poison, or a cancerous growth" $(1973: 1: 79,80)$. The aftereffect of latent meanings or memories takes the form of an afterlife, a spectral or viral mode of livingon. Such "survival meanings" exist in a "twilight state," in a "no man's land" located between the living and the dead: whereas they should be resting eternally in the "cemetery of dead metaphors," they are ready to return and haunt us due to their ability to "become alive and reappear with great vigor" (1973: 2:9). They produce anachronistic constellations of polysemy or homonymy through a spectral mode of linguistic inheritance. It is no wonder Thienemann recurrently expresses his fascination with the way poets, schizophrenics, or dreamers are able to "revive dead metaphors out of the cemetery of forgotten associations and rediscover pathways of associations which once were common, but have been abandoned in the course of history" (1973: 1:33, cf. 1960: 199).

One of Thienemann's own memorable contributions to such a revival of long-dead metaphors concerns the very notion of literature. In one of his autobiographical essays, he proudly claims to have early on discarded literature as an aesthetic concept (belles lettres) in favor of its forgotten reference to "writing" in general, and, by implication, to processes of distribution and reading (2010: 96). His allusion most probably refers to the following passage in Basic Concepts: "Literature begins in fact when the oral tradition is replaced by a tradition of writing and the written word takes over that particular social function of the spoken word, by which the author, the work and the audience become correlated. The history of literature can therefore not be separated from the history of writing and reading, the very word litteratura originally referred to the practice of writing and reading" (1931: 70, my translation). Thienemann's notion of "literature" as literacy (rather than "fiction" or belles lettres) serves as the basis for his final research project on the influence of literacy upon thinking. 
Fogarasi, György. "Idioms and Idiotisms: Theodore Thass-Thienemann's The Interpretation of Language and Spectral Inheritance." Hungarian Cultural Studies. e-Journal of the American Hungarian Educators Association, Volume 12 (2019) DOI: 10.5195/ahea.2019.349

If Thienemann is right in saying, however, that meanings return unaware and uninvited in every bit of speech or writing, then such moments of return have to supersede intentional acts of revival, acts that are willfully committed even by analysts like him who write in a poetic vein. This aspect of language must unconsciously affect not only the language of poets, schizophrenics, or even that of average people like his patients (as he so convincingly demonstrates, for example, in the case of four-year-old Linda, 1973: 1:104-05), but also academic discourse itself. Consequently, it must also affect psychoanalytic discourse, including Thienemann's own contributions, as the Interpretation of Language is surely no exception to the rule. In other words, Thienemann might have to suffer the consequences of his own interpretive success and become the "patient" of his own analytical tool, exposed to a force that, while giving him "strength," also threatens to "poison" his argument and endanger its organic integrity by a "cancerous growth."

One such moment of unintended spectral revival or aftereffect may be detected in Thienemann's brief metapsychological essay on "The Art of Counseling." In attempt to distance himself from the mechanistically biased practices of contemporary analytical and behavioral psychology, Thienemann claims that true counseling is an "art" (a specific form of "spiritual creativity"), rather than a "technique" (1957b: 95). For him, true counseling is oriented toward the spiritual and creative aspects of man with the assumption that man can never be reduced to, or conceived as, a machine (a thought which prefigures his later polemic with seventeenth- and eighteenth-century mechanistic philosophy, cf. 1973: 1:109-10). In what reads like a profession of faith, he places Christian spirituality at the basis of all authentic psychology. The same emotional charge might be lurking behind the former opposition of the dog facing a profane "traffic sign" and the believer facing a sacred "religious symbol" (1973: 1:20). Yet just as religious symbols are sometimes meant to show us the way (much as traffic signs should), and traffic signs are to be trusted unconditionally (as religious symbols are), so too might the initial concepts of art and technique be susceptible to mutual contamination, as far as the Latin term ars can, rather trivially, be translated back into its Greek equivalent, techné. If art is technique, then, to a certain respect, creativity must be mechanical, man a machine, symbolic language reducible to signification, and humans must also be akin to animals, at least according to the unwanted aftereffect of linguistic inheritance. Thienemann's ceaseless defense of the "language barrier" which he conducts against the return of the repressed other (in the image of the subhuman, the animal, the machine, the program etc.) is itself perhaps the symptom of a false pride, of that "human arrogance" (mentioned by Freud and quoted by Thienemann himself in Volume Three; 1984: Part 2, 29), which makes man so self-assured in connection to his cognitive and linguistic abilities, and at the same time so oblivious of all the potential linkages that might relate and even assimilate him to "subhuman" forms of life and existence.

In the "Introduction" to the second volume of the Interpretation, Thienemann expands upon why and how "We do not easily give up our conviction of being perfectly in control of our mother tongue", even though "we are sometimes just performers or actors while we speak," performing a speech, for which "the script is made by someone else" (1973: 2:2). At certain points in his discourse (as is the case above with art and technique, but one could also point to other examples, the uncanny figure of the "gift" of language, for instance, contaminating Thienemann's language by meaning not only "present" but also "poison"), we may have the impression that, by a certain linguistic necessity, he himself has lost his "humble attitude toward language" and has become forgetful concerning his own insight that "sometimes not we are 
Fogarasi, György. "Idioms and Idiotisms: Theodore Thass-Thienemann's The Interpretation of Language and Spectral Inheritance." Hungarian Cultural Studies. e-Journal of the American Hungarian Educators Association, Volume 12 (2019) DOI: 10.5195/ahea.2019.349

speaking our language, but our language is speaking through us as if it were a posthypnotic suggestion implanted into us" (1973: 2:2). What he labels a "posthypnotic suggestion" might very well work as a spectral machine in language, a language unconsciously formulaic, proverbial, parabolic, to the point of infantility, animality, mechanicity, or rather, to the point of linguistic paralysis, senseless stutter, or sheer mindlessness. For, in the end, that is the other possible meaning of idiom as idiotism: a reference not simply to the private idiom of this or that individual, but to the double entendre of all linguistic expressions (words, dream images, or bodily symptoms), which could involve individual speech only inasmuch as they are permeated by "depersonalized formulas" to the point of mental deficiency (1973: 1:156) and which one could no longer unify in the "oneness" or "sameness" of a Jungian archetype or "collective unconscious" (as Thienemann seems at times still willing to do), but should rather accept as the ephemeral and singular return of something that does not let itself be forced into oblivion. For all his resistance to that unwanted return, Thienemann is still a thinker of the spectral in language and thought. In Volume One, he is just as ready to acknowledge that "it speaks through me" (1973: 1:46), as he is ready to admit in Volume Three that "It is thinking in me" (1984: Part 2, 41). Language as well as thought is in possession of the subject, rather than the reverse.

Occasionally returning to his favorite simile of language as a great river, the sources of which are unknown, Thienemann hints at the immense debris of meaning it brings unseen from former generations (1973: 2:225-26; 1984: Preface, 6; Part 2, 41). This puts the speaker out of control and in fact afloat or adrift in his own speech $(1973: 1: 81 ; 1984$ : Part 3, 98). That "drift" also turns language into a kind of "slope" exposing the speaker to the irresistible force of historical gravity (1973: 1:160-61, cf. 81). Thienemann himself seems, as perhaps anyone would be, defenseless against that force. His robust work on the Interpretation of Language amounts to the theory as well as the demonstration of a haunting presence of dead meanings, of a spectral inheritance, ceaselessly and imperceptibly at work even in the language of so erudite a historian and vigilant an interpreter as he is.

\section{Works Cited}

Avilés, Paul. 1999. "The Making of the Face and Heart: Notes on an Aztec Metaphor." Community College Humanities Review 20.1 (Fall): 31-61.

Balogh, Tamás. 2013. Ö volt Thienemann ['Presenting Thienemann']. Budapest: Kijárat. Dávidházi, Péter. 2009. Menj, vándor: Swift sírfelirata és a hagyományrétegződés ['Go, Wanderer: Swift's Epitaph and the Layering of Tradition']. Pécs: Pannónia.

Dávidházi, Péter. 2010. "Egy nagy tudós utolsó önarcképe: Előszó Thienemann Tivadar hazaérkezett emlékirataihoz" ['Self-Portrait of a Scholar: A Preface to the Memoires of Tivadar Thienemann'] Az utókor címére: Életrajzi feljegyzések ['To the Address of Posterity: Biographical Notes’]. Ed. Lajos Koncz. Pécs: Pannónia. 5-15.

Fónagy, Iván. 2001. Languages within Language: An Evolutive Approach. Amsterdam: John Benjamins.

Freud, Sigmund. 2010. The Interpretation of Dreams. Trans. and ed. James Strachey. New York: Basic Books.

Kiséry, András. 2011. "Literacy, Culture, and History in the Work of Thienemann and Hajnal." Comparative Hungarian Cultural Studies. Eds. Steven Tötösy de Zepetnek and Louise O. Vasvári. West Lafayette: Purdue UP. 34-46. 
Fogarasi, György. "Idioms and Idiotisms: Theodore Thass-Thienemann's The Interpretation of Language and Spectral Inheritance." Hungarian Cultural Studies. e-Journal of the American Hungarian Educators Association, Volume 12 (2019) DOI: 10.5195/ahea.2019.349

Koncz, Lajos. 2010. "Utószó” ['Afterword']. Az utókor címére: Életrajzi feljegyzések ['To the Address of Posterity: Biographical Notes']. Ed. Lajos Koncz. Pécs: Pannónia. 151-54.

Kugler, Paul. 2002 (1982). The Alchemy of Discourse: Image, Sound and Psyche (Einsideln: Daimon); re-edition of The Alchemy of Discourse: An Archetypal Approach to Language (Lewisbur, PA: Bucknell UP).

Locke, John. 1997. An Essay on Human Understanding. London: Penguin.

Pesaresi, Massimo Mandolini. 2000. "Review of Gabriele Costa. Le origini della lingua poetica indeuropea: Voce coscienza e transizione neolitica." Annali d'Italianistica 18: 480-82.

Pléh, Csaba. 2016. "Thieneman nyelvpszichológiája a pszichoanalízis és a pszicholingvisztika határán” ['Thienemann's Psychology of Language at the Intersection of Psychoanalysis and Psycholinguistics']. Thienemann Tivadar és a mai szaktudományok: Írások születése 125. évfordulójára ['Tivadar Thienemann and Today's Humanities: Essays on the $125^{\text {th }}$ Anniversary of His Birthday']. Ed. Péter P. Müller. Pécs: Kronosz.

Rogers, Robert. 1978. Metaphor: A Psychoanalytic View. Berkeley and Los Angeles: University of California.

Ronell, Avital. 2002. Stupidity. Urbana: University of Illinois.

Simoncsics, Péter. 2016. "A fordító előszava" ['Translator's Preface'] Thienemann, Tivadar. A nyelv interpretációja ['The Interpretation of Language']. Vol. 1: A nyelv szimbolikus jelentése ['The Symbolic Meaning of Language']. Trans. Péter Simoncsics. Budapest: Tinta. 9-30.

Thass-Thienemann, Theodore. 1955a. "A Comment on an Interpretation by Prof. Cadbury." Gordon Review 1.1 (February): 19-22.

. 1955b. "Left-handed Writing: A Study in the Psychoanalysis of Language." The Psychoanalytic Review 42: 239-61. . 1957a. "Oedipus and the Sphinx: The Linguistic Approach to Unconscious Fantasies." The Psychoanalytic Review 44: 1-33. . 1957b. "The Art of Counseling." Gordon Review 3.3 (September): 95-100. . 1960. "The Talking Teapot - A Note on Psycho-Linguistics." Comprehensive Psychiatry 1: 199-200. . 1963. "Psychotherapy and Psycholinguistics." Topical Problems of Psychotherapy 4:

$37-45$.

. 1967. The Subconscious Language. New York: Washington Square P. 1968. Symbolic Behavior. New York: Washington Square P. 1969. "Response to Reviews of The Subconscious Language." Journal of Communication Disorders 2: 171-73. 1973. The Interpretation of Language. 2 vols. New York: Jason Aronson.

Thienemann, Tivadar. 1931. Irodalomtörténeti alapfogalmak ['Basic Concepts of Literary History']. Pécs: Danubia. . 2010. Az utókor címére: Életrajzi feljegyzések ['To the Address of Posterity: Biographical Notes']. Ed. Lajos Koncz. Pécs: Pannónia. 